\title{
The Peruvian sardine, Sardinops sagax: Historical analysis of the fishery (1978-2005)
}

\section{La sardina peruana, Sardinops sagax: Análisis histórico de la pesquería (1978-2005)}

\author{
Gladys Cárdenas-Quintana*, Milagros Franco-Meléndez, José Salcedo-Rodríguez, \\ Dany Ulloa-Espejo, José Pellón-Farfán \\ Instituto del Mar del Perú (IMARPE), Esquina Gamarra y Gral. Valle, s/n, PO Box 22, Chucuito, Callao, Perú \\ * Corresponding author. E-mail: gcardenas@imarpe.gob.pe
}

\begin{abstract}
The historical development of Peru's sardine (Sardinops sagax) fishery between 1978 and 2005 is described from fishery indicators (landings and effort) and environmental indicators (Pacific Decadal Oscillation [PDO] index, Southern Oscillation Index, and Sea Surface Temperature Anomaly) in order to observe the spatial and temporal variations of the fishery. During this period, the fishery indicators showed that excessive fishing pressure caused the drastic decline in abundance, as demonstrated by the low catch levels in recent years. Regarding the environmental indicators, a positive relationship with sardine landing anomalies was observed; however, the PDO index had a significant positive correlation $\left(r_{\text {Pearson }}=0.50 ; P=0.0005 ; n=45\right)$ in comparison with the other indices. The results of this study show that the effects of overfishing and adverse environmental conditions strongly impacted the Peruvian sardine population, with the consequent collapse of the fishery.
\end{abstract}

Key words: Peruvian sardine, fishery, environmental variability, availability, Peru.

RESUMEN. Se describe el desarrollo histórico de la pesquería de la sardina Sardinops sagax en el Perú entre los años 1978 y 2005 a partir de indicadores pesqueros (desembarques y esfuerzo) e indicadores ambientales (Índice de Oscilación Decadal del Pacífico [IODP], Índice de Oscilación del Sur y Anomalías de la Temperatura Superficial del Mar) con la finalidad de observar variaciones espaciotemporales de la pesquería. Durante este periodo, los indicadores pesqueros demostraron que la excesiva presión de pesca sobre este recurso propició la drástica disminución de la abundancia, lo cual se reflejó en los bajos niveles de captura en los últimos años. Respecto a los indicadores ambientales, se observó una relación positiva con las anomalías de desembarque de sardina; el IODP presentó la mejor correlación positiva $\left(r_{\text {Pearson }}=0.50\right.$; $P=0.0005 ; n=45)$ en comparación con los otros índices. Los resultados de este estudio muestran que el efecto de la intensa actividad extractiva y las condiciones ambientales adversas impactaron fuertemente en la población de sardina, con el consiguiente colapso de su pesquería.

Palabras clave: sardina peruana, pesquería, variabilidad ambiental, disponibilidad, Perú.

\section{INTRODUCTION}

Populations of small pelagic fish such as sardines and anchovies are found in highly productive ecosystems, especially upwelling regions, around the world. These species account for nearly one-third of the global fish catches, mainly in the Humboldt, Benguela, California, and Canary current systems (FAO 2007).

The northern Humboldt Current System off Peru is highly dynamic. Besides its high biological productivity, it exhibits high climate and oceanographic variability associated with seasonal, interannual (El Niño/La Niña), decadal, and longterm changes (Csirke and Gumy 1996, Bakun and Broad 2003, Chávez et al. 2003).

The Peruvian sardine, Sardinops sagax (Jenyns 1842), inhabits this environment. This species used to be one of the main sources of raw material for Peru's canning industry and of great socio-economic importance for the country,

\section{INTRODUCCIÓN}

En ecosistemas altamente productivos del mundo, particularmente en zonas de afloramiento, habitan grandes poblaciones de pequeños peces pelágicos como la sardina y la anchoveta. Estas especies contribuyen con alrededor de la tercera parte de las capturas globales de peces, particularmente en los sistemas de las corrientes de Humboldt, Benguela, California y Canarias (FAO 2007).

El Sistema de la Corriente de Humboldt del norte frente al Perú es muy dinámico. Además de su alta productividad biológica, se caracteriza por presentar una alta variabilidad climática y oceanográfica asociada con cambios estacionales, interanuales (El Niño y La Niña), decadales y de largo plazo (Csirke y Gumy 1996, Bakun y Broad 2003, Chávez et al. 2003).

En este escenario ambiental habita la sardina peruana, Sardinops sagax (Jenyns 1842). Esta especie tuvo gran 
particularly during the 1980 s. It also plays an important ecological role in the transfer of energy from lower to higher trophic levels and as prey for a number of higher-level predators like large fish, birds, and marine mammals (Cury et al. 2000). Over the last three decades, however, the sardine population in Peruvian waters has experienced notable changes in distribution and abundance levels as a result of overfishing and environmental factors, and has declined to very low levels as evidenced by the fall in sardine landings (Patterson et al. 1992, Csirke and Gumy 1996, Cárdenas et al. 1997).

The objective of the present study is to analyze the historical development of the sardine fishery from 1978 to 2005 based on fishery indicators (fishing effort and landings), spatial and temporal distribution, and environmental indicators, factors that interact in complex and unexpected ways and affect the population. This information will allow a better assessment of the sardine fishery and thus help to develop appropriate management measures that will ensure its recovery.

\section{MATERIALS AND METHODS}

The study area included the coastal zone off Peru, from the northern border (Puerto Pizarro, $03^{\circ} 30^{\prime} \mathrm{S}, 80^{\circ} 24^{\prime} \mathrm{W}$ ) to the southern border ( $\mathrm{La}$ Concordia, $18^{\circ} 20.8^{\prime} \mathrm{S}, 70^{\circ} 22.6^{\prime} \mathrm{W}$ ), and 200 nautical miles $(\mathrm{nm})$ offshore. Three regions were considered for the analysis: northern, central, and southern (fig. 1).

The fishing effort and landing data (fishery indicators) were obtained from the project "Seguimiento de la pesquería de anchoveta y otros recursos pelágicos" (Monitoring of the anchovy fishery and other pelagic resources) carried out by the Instituto del Mar del Perú (IMARPE) from 1978 to 2005. Daily landing records per vessel were collected and examined based on subsamples of species composition. Fishing effort was determined considering the number and type of purse seine vessels and storage capacity $\left(\mathrm{m}^{3}\right)$.

The charts of the distribution and concentration of sardine catches were georeferenced using a geographic information system (ArcGIS v9.3). The years of the historical landing series were grouped by decades considering the mean cumulative catches per maritime area of $10 \mathrm{~nm}$, parallel to the coastline every half-degree of latitude (isoparalittoral areas).

Data (1961-2005) on the following environmental indicators were used: the Pacific Decadal Oscillation (PDO) index, the Southern Oscillation Index (SOI), and Sea Surface Temperature Anomalies (SSTA) (1961-2005) from a fixed coastal station (Chimbote). The monthly sardine landing anomalies (SardAnom, dimensionless) were calculated as follows:

$$
\text { SardAnom }=\frac{D_{\text {SardMonth }}-D_{\text {SardPattern }}}{D_{\text {AvgTotal }}}
$$

where $D_{\text {SardMonth }}$ is the the original monthly sardine landing datum (tons), $D_{\text {SardPattern }}$ is the sardine landing pattern (tons) importancia socioeconómica para el Perú, con auge en la década de 1980, por constituir una de las principales fuentes de materia prima para la industria conservera. Además, ha jugado un rol ecológico importante en la transferencia de energía desde bajos hacia altos niveles tróficos y como presa de numerosos depredadores superiores, como peces grandes, aves y mamíferos marinos (Cury et al. 2000). En las últimas tres décadas, la población de sardina en aguas peruanas ha experimentado cambios notables en su distribución, niveles de abundancia y desembarques relacionados con factores ambientales y la presión de pesca. Los referidos factores han originado el descenso de su abundancia a niveles muy bajos, lo que se refleja en los desembarques (Patterson et al. 1992, Csirke y Gumy 1996, Cárdenas et al. 1997).

El presente trabajo tiene como objetivo analizar la pesquería de S. sagax durante la serie histórica 1978-2005 teniendo en cuenta los indicadores de la pesquería (desembarques y esfuerzo pesquero), la distribución espaciotemporal de la especie y los indicadores ambientales, que son factores que interactúan de manera compleja e inesperada e impactan sobre la población. Este estudio permitirá hacer un mejor diagnóstico de la pesquería de sardina y, por lo tanto, una mejora en el asesoramiento y gestión para garantizar su recuperación.

\section{MATERIALES Y MÉTODOS}

El área de estudio abarcó todo el litoral peruano, desde puerto Pizarro $\left(03^{\circ} 30^{\prime} \mathrm{S}, 80^{\circ} 24^{\prime} \mathrm{W}\right)$ en la frontera norte hasta La Concordia $\left(18^{\circ} 20.8^{\prime} \mathrm{S}, 70^{\circ} 22.6^{\prime} \mathrm{W}\right)$ en la frontera sur, y desde la línea de la costa hasta las 200 millas náuticas $(\mathrm{mn})$. Para el análisis se consideraron tres regiones: norte, centro y sur (fig. 1).

La información de los indicadores pesqueros (desembarques y esfuerzo) provino del proyecto "Seguimiento de la pesquería de anchoveta y otros recursos pelágicos" ejecutado por el Instituto del Mar del Perú (IMARPE) desde 1978 hasta 2005. Se obtuvieron registros diarios de desembarques por embarcación y se realizaron submuestreos de la composición por especie. El esfuerzo de pesca se determinó teniendo en cuenta el número y tipo de embarcaciones de cerco que operaron y la capacidad de bodega $\left(\mathrm{m}^{3}\right)$.

Los mapas de distribución y concentración de las capturas de sardina fueron georeferenciados mediante el uso de un sistema de información geográfica (ArcGIS v9.3). Se agruparon los años de la serie histórica de desembarques por décadas teniendo en cuenta las capturas acumuladas promedio por áreas marítimas de $10 \mathrm{mn}$ de extensión, paralelas a la costa por cada medio grado de latitud (áreas isoparalitorales).

Se utilizaron datos (1961-2005) de los siguientes indicadores ambientales: el Índice de Oscilación Decadal del Pacífico (IODP); el Índice de Oscilación del Sur (IOS); y las Anomalías de la Temperatura Superficial del Mar (ATSM), estas últimas de la estación fija costera de Chimbote. Las anomalías de las series mensuales de los desembarques de 


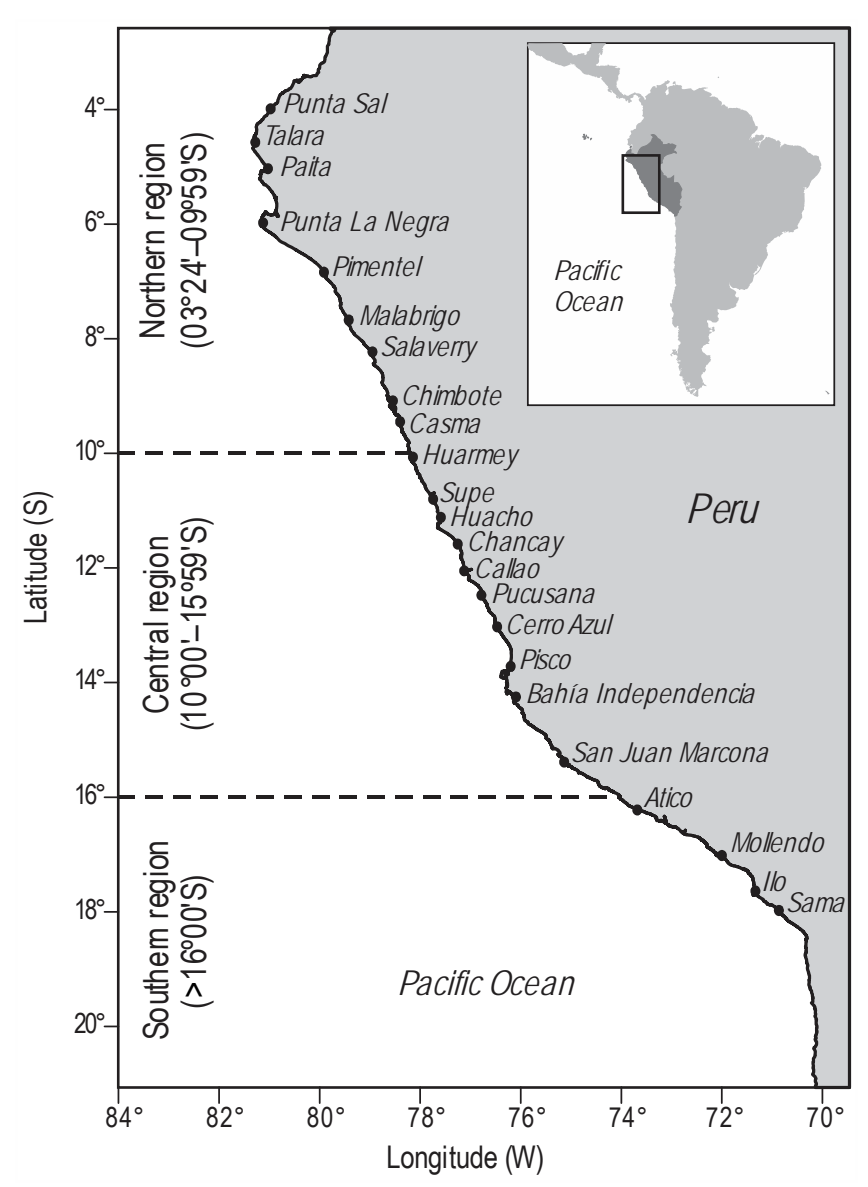

Figure 1. Study area along the Peruvian coast.

Figura 1. Área de estudio a lo largo de la costa peruana.

from 1961 to 2005 , and $D_{\text {AvgTotal }}$ is the monthly average total sardine landing (tons). The physical and biological (sardine landing anomalies) time series were then linearly related based on a polynomial regression (better fit obtained with order 6), as follows:

$$
Y_{\text {SardAnom }}=a_{0}+a_{1} X+a_{2} X^{2}+\ldots+a_{d} X^{d}
$$

where $Y_{\text {SardAnom }}$ is the sardine landing anomaly (dimensionless), $X$ are the years (1961-2005), and $a_{0} \ldots a_{d}$ are the coefficients of the equation.

\section{RESULTS}

\section{Fishing effort}

\section{Types of fishing vessels and gear}

The Peruvian vessels targeting sardine, known locally as bolicheras, mainly use purse seine nets. Three types of fleet operated during the study period (table 1):

- Industrial fleet, consisting of vessels equipped with refrigeration systems that used nets with a mesh size of sardina (AnomSard, adimensional) se calcularon mediante la siguiente expresión:

$$
\text { AnomSard }=\frac{\left(D_{\text {SardMes }}-D_{\text {SardPatrón }}\right)}{D_{\text {PromTotal }}}
$$

donde $D_{\text {Sardmes }}$ es el desembarque (toneladas) de sardina mensual del dato original, $D_{\text {SardPatrón }}$ es el promedio del patrón de desembarque (toneladas) de sardina en el periodo 1961-2005 y $D_{\text {PromTotal }}$ es el desembarque (toneladas) de sardina promedio total mensual. Se relacionaron linealmente las series de tiempo físicas con las biológicas (anomalías de los desembarques de sardina) considerando una regresión polinomial (mejor ajuste obtenido con ordenación de 6):

$$
Y_{\text {AnomSard }}=a_{0}+a_{1} X+a_{2} X^{2}+\ldots+a_{d} X^{d}
$$

donde $Y_{\text {Anomsard }}$ es la anomalía de desembarque de sardina (adimensional), $X$ corresponde a los años (1961-2005) y $a_{0} \ldots a_{d}$ son los coeficientes de la ecuación.

\section{RESULTADOS}

\section{Esfuerzo pesquero}

Tipos de embarcaciones y artes de pesca

Las embarcaciones que se dedican a la pesca de sardina, conocidas localmente como bolicheras, operaron mayormente con red de cerco. Durante el período de estudio se identificaron tres tipos de flotas (tabla 1):

- Flota industrial conformada por embarcaciones equipadas con sistemas de refrigeración que usaron redes con tamaño de malla de $38 \mathrm{~mm}$ (red sardinera). La capacidad de bodega (CB) de estas embarcaciones representó el $27 \%$ de la $\mathrm{CB}$ total operativa. Las capturas de sardina fueron destinadas al consumo humano directo (CHD), principalmente a la elaboración de conservas.

- Flota industrial conformada por embarcaciones sin sistema de refrigeración que utilizaron indistintamente redes con tamaños de malla de $13 \mathrm{~mm}$ (red anchovetera) y $38 \mathrm{~mm}$. Fue la flota más numerosa, y la $\mathrm{CB}$ representó más del 70\% de la $\mathrm{CB}$ operativa. El destino de las capturas fue la producción de harina y aceite de pescado (consumo humano indirecto, $\mathrm{CHI}$ ).

- Flota artesanal conformada por embarcaciones cuya capacidad de bodega fue menor que $30 \mathrm{~m}^{3}$ y que operaron dentro de las $5 \mathrm{mn}$ de la costa. En el periodo entre 1983 y 1995 , la producción fue de $26,000 \mathrm{t}$ de sardina por año $\mathrm{y}$ fue utilizada en la conservería (CHD) y como carnada. 
Table 1. Type of fleet and characteristics of the vessels dedicated to sardine (Sardinops sagax) fishing.

Tabla 1. Tipo de flota y características de las embarcaciones dedicadas a la extracción de sardina (Sardinops sagax).

\begin{tabular}{|c|c|c|c|}
\hline Type of fleet and fishing gear & Target species & Destination & Comments \\
\hline $\begin{array}{l}\text { Purse seine fleet with refrigeration } \\
\text { systems (refrigerated seawater and chilled } \\
\text { seawater); 38-mm mesh-size net }\end{array}$ & $\begin{array}{l}\text { Sardine } \\
\text { Jack mackerel } \\
\text { Chub mackerel }\end{array}$ & $\begin{array}{l}\text { Canning } \\
\text { Fishmeal and fish oil }\end{array}$ & $\begin{array}{l}\text { This fleet represented } 27 \% \text { of the } \\
\text { hold capacity during the period } \\
1970-1985\end{array}$ \\
\hline $\begin{array}{l}\text { Purse seine fleet without } \\
\text { refrigeration systems; } \\
\text { 13- and 38-mm mesh-size nets }\end{array}$ & $\begin{array}{l}\text { Anchovy } \\
\text { Sardine }\end{array}$ & Fishmeal and fish oil & $\begin{array}{l}\text { The most numerous fleet; it } \\
\text { represented } 70 \% \text { of total landings } \\
\text { in the } 1980 \mathrm{~s}\end{array}$ \\
\hline $\begin{array}{l}\text { Artisanal fleet with hold capacity of } \\
<30 \mathrm{~m}^{3} \text {, operating within } 5 \text { nautical miles } \\
\text { from the coast }\end{array}$ & Sardine & $\begin{array}{l}\text { Canning } \\
\text { Bait (fresh and/or frozen) }\end{array}$ & $\begin{array}{l}\text { Catch capacity of } 26,000 \mathrm{t} \mathrm{yr}^{-1} \\
\text { between } 1983 \text { and } 1995\end{array}$ \\
\hline
\end{tabular}

$38 \mathrm{~mm}$ (sardine net). The hold capacity (HC) of these vessels represented $27 \%$ of the total operative $\mathrm{HC}$. The sardine catches were destined for direct human consumption (DHC), mainly for canning.

- Industrial fleet, consisting of vessels not equipped with refrigeration systems that used nets with mesh sizes of $13 \mathrm{~mm}$ (anchovy net) and $38 \mathrm{~mm}$. This was the largest fleet, the $\mathrm{HC}$ representing more than $70 \%$ of the operative $\mathrm{HC}$. The catches were destined for indirect human consumption (IHC), mainly for the production of fishmeal and fish oil.

- Artisanal fleet, consisting of vessels with a $\mathrm{HC}$ of $<30 \mathrm{~m}^{3}$, operating within $5 \mathrm{~nm}$ from the shore. Between 1983 and 1995 this fleet landed 26,000 t of sardine per year, used for DHC (canning) and as bait.

By the end of the 1990s, commercial fishing vessels, with a $\mathrm{HC}$ of 50 to $800 \mathrm{~m}^{3}$, were using modern fish-finding instruments, and catching both anchovy (Engraulis ringens) and sardine for the production of fishmeal and fish oil.

\section{Number of vessels and hold capacity}

Fishing effort, translated into number of vessels and $\mathrm{HC}$ during the study period, varied significantly per type of industrial fleet (DHC, IHC) (fig. 2). When commercial fishing began (1978-1979), an average of 241 vessels targeted fish for DHC, mainly for canning but also for the production of fishmeal and fish oil. In turn, the fleet targeting fish for IHC operated with 494 vessels, on average, with a mean HC equivalent to $139,160 \mathrm{~m}^{3}$.

During the 1980s, period when the sardine fishery saw greatest expansion, the average number of vessels fishing for DHC was 292, with an average $\mathrm{HC}$ of $36,473 \mathrm{~m}^{3}$. The fleet fishing for IHC consisted of 356 vessels, with an average $\mathrm{HC}$ of $96,376 \mathrm{~m}^{3}$.
A finales de la década de 1990, las embarcaciones industriales (CB de entre 50 y $800 \mathrm{~m}^{3}$ ) utilizaron equipos modernos de localización de cardúmenes y monitoreo satelital, y capturaron tanto anchoveta (Engraulis ringens) como sardina para la producción de harina y aceite de pescado.

\section{Número de embarcaciones y capacidad de bodega}

El esfuerzo pesquero, traducido en número de embarcaciones y capacidad de bodega durante el período de estudio, varió significativamente según el tipo de flota industrial (CHD, CHI) (fig. 2). A inicios de la pesquería industrial (1978-1979) operaron, en promedio, 241 embarcaciones dirigidas a la pesca para CHD, cuyo destino fue la industria de conservas principalmente y la elaboración de harina y aceite de pescado. En cambio, la flota industrial dirigida a la pesca para CHI operó con 494 embarcaciones, en promedio con una equivalente a $139,160 \mathrm{~m}^{3}$.

En la década de 1980, considerada como el periodo de mayor desarrollo de la pesquería de sardina, el número promedio de embarcaciones dirigidas a la pesca para CHD fue de 292 , con una CB promedio de $36,473 \mathrm{~m}^{3}$. La flota dirigida a la pesca para $\mathrm{CHI}$ fue de 356 embarcaciones, con una $\mathrm{CB}$ promedio de $96,376 \mathrm{~m}^{3}$.

De 1990 a 1993, el número de embarcaciones dirigidas a la pesca para CHD disminuyó a un promedio de 199. Por el contrario, la flota dirigida a la pesca para CHI aumentó a un promedio de 435 embarcaciones, con una $\mathrm{CB}$ promedio de $113,044 \mathrm{~m}^{3}$. No se contó con información sobre el esfuerzo de la flota dirigida a la pesca para CHD después de 1994 porque no ha sido posible establecer diferencias entre ambas flotas (CHD y CHI), ya que ambas usaban indistintamente tanto la red anchovetera como la red sardinera para la captura de ambas especies.

Entre 1994 y 1998, la flota industrial dirigida a la pesca para $\mathrm{CHI}$ representó en promedio 614 bolicheras, con una $\mathrm{CB}$ de $155,487 \mathrm{~m}^{3}$. Estas embarcaciones capturaban indistintamente anchoveta y sardina. Sin embargo, el mayor esfuerzo 


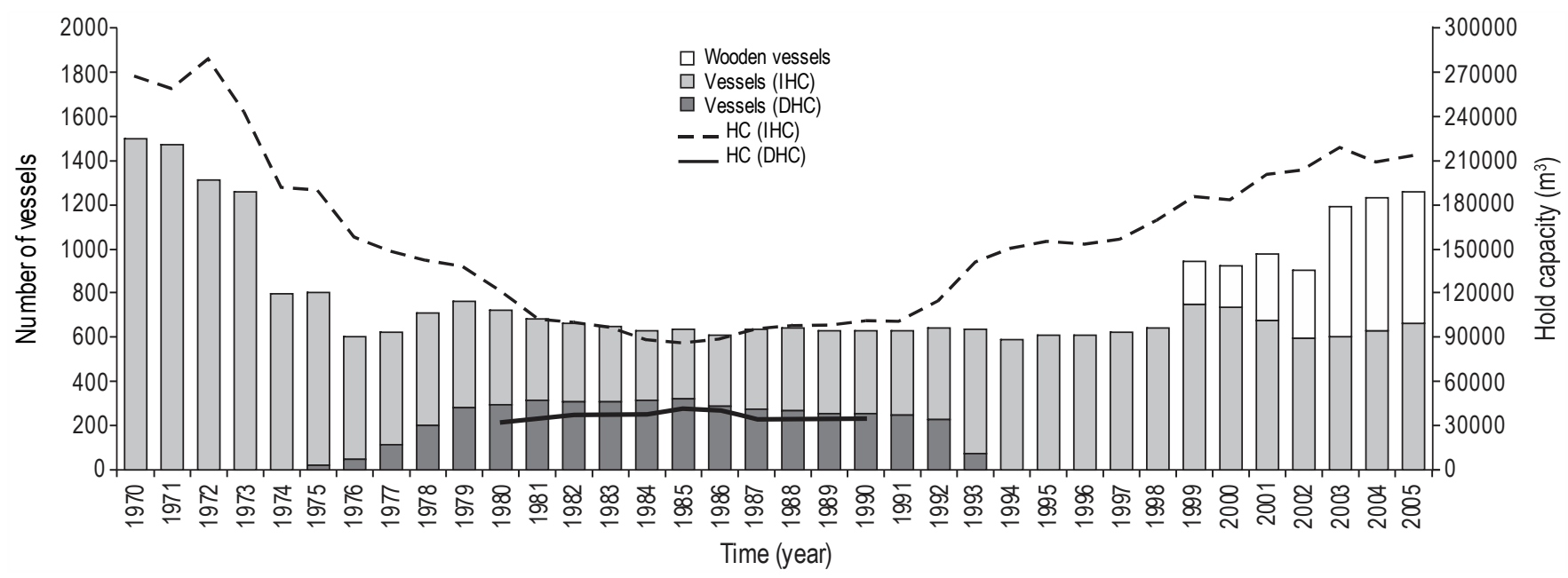

Figure 2. Number of purse seine vessels (steel and wooden) and hold capacity (HC) of the Peruvian industrial fleet targeting anchovy and sardine for indirect human consumption (IHC) and direct human consumption (DHC) during the period from 1970 to 2008.

Figura 2. Número de embarcaciones de cerco (de acero y de madera ["vikingas"]) y capacidad de bodega (HC) de la flota industrial peruana dirigida a la pesca de sardina y anchoveta para consumo humano indirecto (IHC) y consumo humano directo (DHC) durante el periodo comprendido entre 1970 y 2008.

From 1990 to 1993, the number of vessels fishing for DHC decreased to an average of 199. Conversely, the number of vessels fishing for IHC increased to an average of 435 , with a $\mathrm{HC}$ of $113,044 \mathrm{~m}^{3}$. There is no information on fishing effort for the fleet targeting fish for DHC after 1994 because it has not been possible to establish differences between both fleets (DHC and IHC), since both the anchovy net and the sardine net were used indistinctly to capture both species.

Between 1994 and 1998, the industrial fleet fishing for IHC consisted of an average of 614 vessels, with a HC of $155,487 \mathrm{~m}^{3}$. These beach seiners indistinctly captured both anchovy and sardine; however, the greatest effort directed towards sardine was recorded in 1998, when the fleet consisted of 642 vessels.

During the period 1999-2005, when the sardine catches declined abruptly, the effort was almost exclusively directed towards anchovy.

\section{Historical landings}

The historical series of sardine landings (1970-2005) showed that catch levels were low in the early 1970s. When the anchovy fishery collapsed in 1972, sardine landings increased, reaching 132,000 and 72,000 $\mathrm{t}$ in 1973 and 1974, respectively. The industrial sardine fishery initiated in 1978; annual landings were $\sim 1.5$ million tons until 1982, decreasing in 1983 (El Niño year) to $\sim 1$ million tons.

The highest volumes of sardine landings were recorded during the 1980s (except during the 1982-1983 El Niño event), reaching a maximum of 3.5 million tons in 1988 . After 1990, the catches decreased to average annual levels of pesquero dirigido a la sardina se registró en 1998, cuando operaron 642 embarcaciones.

En el período 1999-2005, cuando las capturas de sardina decrecieron abruptamente, el esfuerzo se dirigió casi exclusivamente a la anchoveta.

\section{Desembarques históricos}

La serie histórica de los desembarques de sardina (1970-2005) mostró que a inicios de los años setenta, las capturas fueron bajas. Con el colapso de la pesquería de anchoveta en 1972, los desembarques de sardina se incrementaron hasta alcanzar cifras de 132,000 y 72,000 t en los años 1973 y 1974, respectivamente. La pesquería industrial de sardina se inició en 1978 con un desembarque anual aproximado de 1.5 millones de toneladas hasta 1982, que disminuyó a cifras de alrededor de 1 millón de toneladas en 1983 (El Niño).

En la década de 1980, se registraron los mayores volúmenes de desembarque de sardina (excepto durante El Niño 1982-1983), incluyendo la cifra máxima de 3.5 millones de toneladas en 1988. A partir de 1990, las capturas decrecieron a niveles promedio anuales cercanos a 1 millón de toneladas en el periodo 1992-1998, y luego a $132 \mathrm{t}$.

Los mayores desembarques de sardina en toda la serie de tiempo analizada se registraron en la región norte-centro del litoral peruano, principalmente en los puertos del norte como Chimbote $\left(09^{\circ} 04^{\prime} \mathrm{S}, 78^{\circ} 36^{\prime} \mathrm{W}\right)$ y Paita $\left(05^{\circ} 04^{\prime} \mathrm{S}, 81^{\circ} 06^{\prime} \mathrm{W}\right)$, de donde provinieron entre el $40 \%$ y $75 \%$ de los desembarques, excepto durante El Niño 1982-1983. En la zona sur, los desembarques fueron poco significativos (fig. 3). 
$\sim 1$ million tons during the period 1992-1998. The levels subsequently decreased to $132 \mathrm{t}$.

The highest sardine landings of all the time series analyzed were recorded in the northern and central regions of the Peruvian littoral, mainly in northern ports such as Chimbote $\left(09^{\circ} 04^{\prime} \mathrm{S}, 78^{\circ} 36^{\prime} \mathrm{W}\right)$ and Paita $\left(05^{\circ} 04^{\prime} \mathrm{S}, 81^{\circ} 06^{\prime} \mathrm{W}\right)$, from where between $40 \%$ and $75 \%$ of the landings originated, except during the 1982-1983 El Niño event. In the southern region, the landings were not very significant (fig. 3).

During the 1980s and 1990s, the sardine landings showed seasonality, the highest landings occurring during the austral summer and spring (fig. 4).

\section{Alternation of sardine and anchovy landings}

Changes in the dominance of sardine and anchovy indicate an alternation between the sardine and anchovy landings (fig. 5). During the 1950s and 1960s the pelagic fishery was sustained by anchovy catches. The sardine landings were at that time limited to a few tens of thousands of tons but increased substantially after commercial sardine fishing began in 1978. During the 1980s, sardines dominated, the cumulative landings reaching 21 million tons, compared to 16 million tons for anchovy. After 1990, the anchovy landings began to increase and the sardine landings slowly decreased to $360 \mathrm{t}$ in 2003, after which they were almost nil.

\section{Spatial and temporal distribution of sardine catches}

The distribution of sardine catches showed significant spatial and temporal variations off the coast of Peru (fig. 6).
Para las décadas de 1980 y 1990, se observó una estacionalidad en los desembarques de sardina, con los mayores rendimientos en el verano y la primavera austral (fig. 4).

\section{Alternancia en los desembarques de sardina y anchoveta}

Los cambios en la dominancia de la sardina y anchoveta en los desembarques evidenciaron una alternancia entre ambas especies (fig. 5). En las décadas de 1950 y 1960, la pesquería pelágica se sustentó con capturas de anchoveta; los desembarques de sardina se limitaron a unas decenas de miles de toneladas. A partir de 1978 se inició la pesquería industrial de la sardina, con capturas significativas. En la décdada de 1980, la dominancia de la sardina se reflejó en los valores más altos de sus desembarques acumulados, que alcanzaron 21 millones de toneladas, mientras que los desembarques de anchoveta representaron 16 millones de toneladas. A partir de 1990, los desembarques de anchoveta incrementaron, en tanto que los de sardina fueron disminuyendo paulatinamente, hasta llegar a $360 \mathrm{t}$ en 2003 , y posteriormente fueron casi nulas.

\section{Distribución espaciotemporal de las capturas de sardina}

La distribución de las capturas de sardina presentó variaciones espaciales y temporales significativas en el litoral peruano (fig. 6). En la década de 1980, la sardina presentó una distribución latitudinal amplia, desde Paita hasta la frontera sur (Ilo), con núcleos de concentración muy importantes: frente a Chimbote y Paita en la región norte y frente a Callao $\left(12^{\circ} 00^{\prime} \mathrm{S}, 77^{\circ} 04^{\prime} \mathrm{W}\right)$ en la región centro e Ilo $\left(17^{\circ} 38^{\prime} \mathrm{S}\right.$,

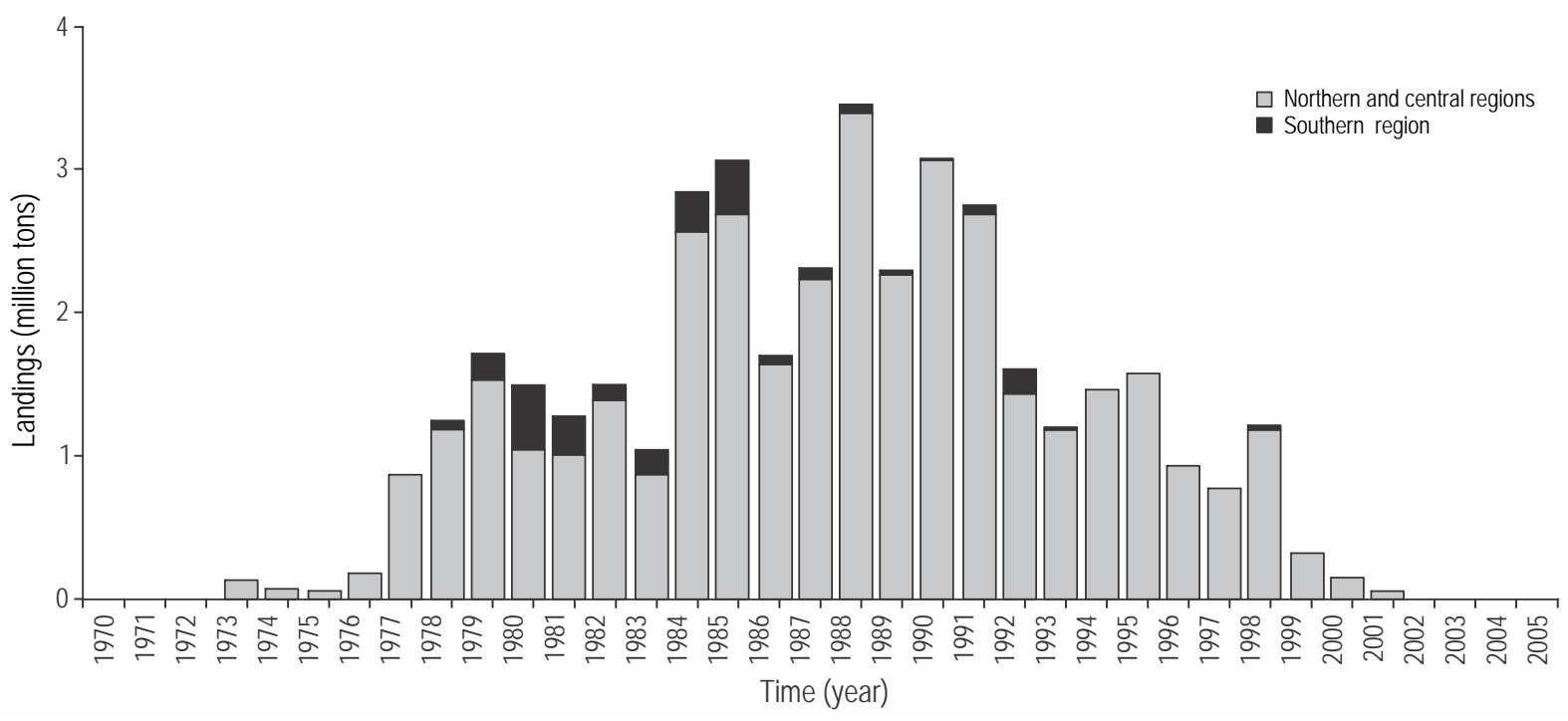

Figure 3. Time series of annual landings (million tons) of the sardine Sardinops sagax (Jenyns 1842) by regions off the Peruvian coast (1970-2006).

Figura 3. Serie histórica de desembarques (millones de toneladas) anuales de sardina la Sardinops sagax (Jenyns 1842) según regiones en el litoral peruano (1970-2006). 


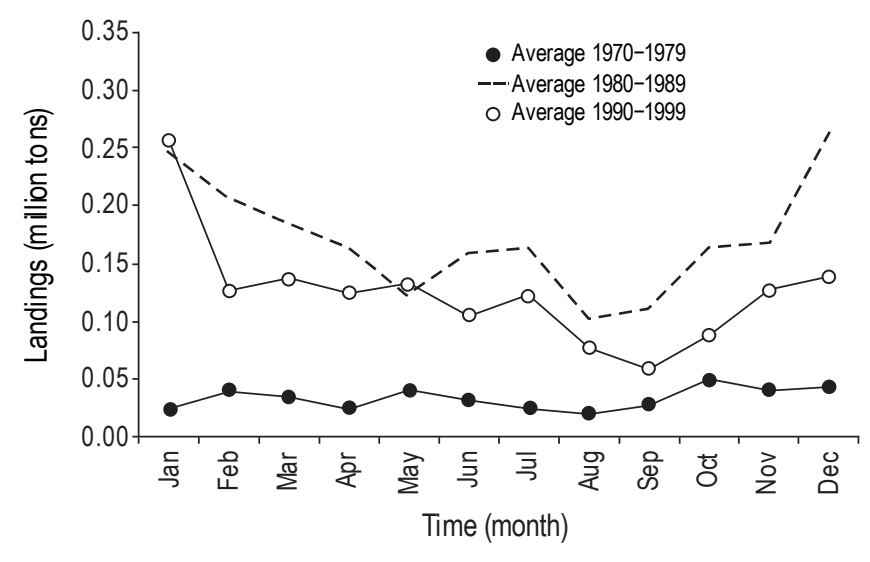

Figure 4. Monthly comparison of sardine (Sardinops sagax) landings by decades.

Figura 4. Comparación de los desembarques mensuales de sardina (Sardinops sagax) según las décadas.

During the 1980s, S. sagax showed a wide latitudinal distribution, from Paita in the north to Ilo in the south, and some main centers of concentration: off Chimbote and Paita in the northern region, off Callao $\left(12^{\circ} 00^{\prime} \mathrm{S}, 77^{\circ} 04^{\prime} \mathrm{W}\right)$ in the central region, and off Ilo $\left(17^{\circ} 38^{\prime} \mathrm{S} ; 71^{\circ} 20^{\prime} \mathrm{W}\right)$ in the southern region. These fishing areas were the most important during the period under study, yielding catches of $>700,000 \mathrm{t}$, especially between 10 and $70 \mathrm{~nm}$ and up to $100 \mathrm{~nm}$ offshore. During this period, the concentrations of sardine were higher in areas close to shore.

In the early 1990s, the main areas of concentration were similar to those of the previous decade, but the catches were smaller. By the late 1990s, the fishing areas were more scattered, extending to $200 \mathrm{~nm}$ offshore. This wide distribution continued from 2000 to 2005 , with yields of $\sim 5000 \mathrm{t}$.

\section{Comparison of Peruvian, Ecuadorian, and Chilean sardine landings}

The comparative analysis of the landings of the northerncentral Peru and southern Ecuador stock showed that Peru contributed more than $90 \%$ of the annual landings during the period from 1982 to 1996 (fig. 7a). The largest landing recorded in Peru was 3.5 million tons in 1988 and the largest landing recorded in Ecuador was 1.2 million tons in 1985. The landings decreased significantly in subsecuent years, but Peru's contribution was always higher, except from 2000 to 2005.

Conversely, in the case of the southern Peru and northern Chile stock, during the period from 1980 to 2005 Peru contributed only $10 \%$ of the total landings and Chile the rest (fig. 7b). Total landings (southern Peru and northern Chile) and landings per country decreased after 1985 and notably so after 1994, except in 1992, when there was a slight increase. The largest landing in southern Peru $(\sim 458,000 \mathrm{t})$ was recorded in 1980, and in Chile (2.6 million tons), in 1985. $71^{\circ} 20^{\prime} \mathrm{W}$ ) en la región sur. Estos núcleos fueron los más importantes durante el periodo evaluado, con registros de captura superiores a las 700,000 t, principalmente desde las 10 hasta las $70 \mathrm{mn}$ de la costa pero también hasta las $100 \mathrm{mn}$. Durante esta época la sardina mostró mayores concentraciones en áreas cercanas a la costa.

A inicios de la década de 1990, la sardina presentó núcleos de concentración en lugares similares a los observados en la década anterior, aunque los desembarques fueron menores. Hacia finales de los noventa, la sardina presentó una mayor dispersión hasta las $200 \mathrm{mn}$ y mantuvo esta distribución amplia durante los años 2000 a 2005, con rendimientos bajos de alrededor de $5000 \mathrm{t}$.

\section{Desembarques comparativos de sardina de las poblaciones pesqueras frente a Perú, Ecuador y Chile}

El análisis comparativo de los desembarques de la población pesquera del norte-centro del Perú y sur del Ecuador mostró que el Perú contribuyó con más del $90 \%$ de los desembarques anuales en el período de 1982 a 1996 (fig. 7a). El mayor desembarque registrado para el Perú fue de 3.5 millones de toneladas en 1988 y para Ecuador fue de 1.2 millones de toneladas en 1985. En años posteriores, los desembarques disminuyeron significativamente en ambos países, pero siempre el Perú aportó con mayores capturas, excepto en el periodo de 2000 a 2005.

Por el contrario, para la población pesquera de sardina del sur del Perú y norte de Chile, entre 1980 y 2005, los mayores desembarques correspondieron a Chile y sólo el $10 \%$ del total correspondió al Perú (fig. 7b). Los desembarques totales (sur del Perú y norte de Chile) y los desembarques por país decrecieron a partir de 1985 y aún más a partir de 1994, a excepción del año 1992, en el cual se presentó un ligero incremento. El mayor desembarque en el sur del Perú ocurrió en 1980, con alrededor de 458,000 t, y en Chile fue en 1985, con 2.6 millones de toneladas.

\section{Disponibilidad de la sardina frente a la variabilidad ambiental}

Se observó una correlación significativa entre las anomalías de los desembarques de sardina y los indicadores climáticos (IODP, IOS y ATSM). Las anomalías de los desembarques de este recurso mantuvieron una relación positiva con los IODP. Los desembarques muy bajos estuvieron asociados a valores negativos del IODP, desde 1961 hasta 1975. Entre 1979 y 1998, cuando los desembarques se incrementaron, los valores de este índice fueron positivos. A partir de 1999 se repite la tendencia observada en los primeros años. Esto indica fluctuaciones de largo plazo en los desembarques, es decir, periodos de altos y bajos rendimientos (fig. 8a).

El IOS confirmó esta fluctuación de largo plazo de los desembarques durante los períodos fríos y cálidos de la serie histórica 1961-2005 asociados a valores positivos y 


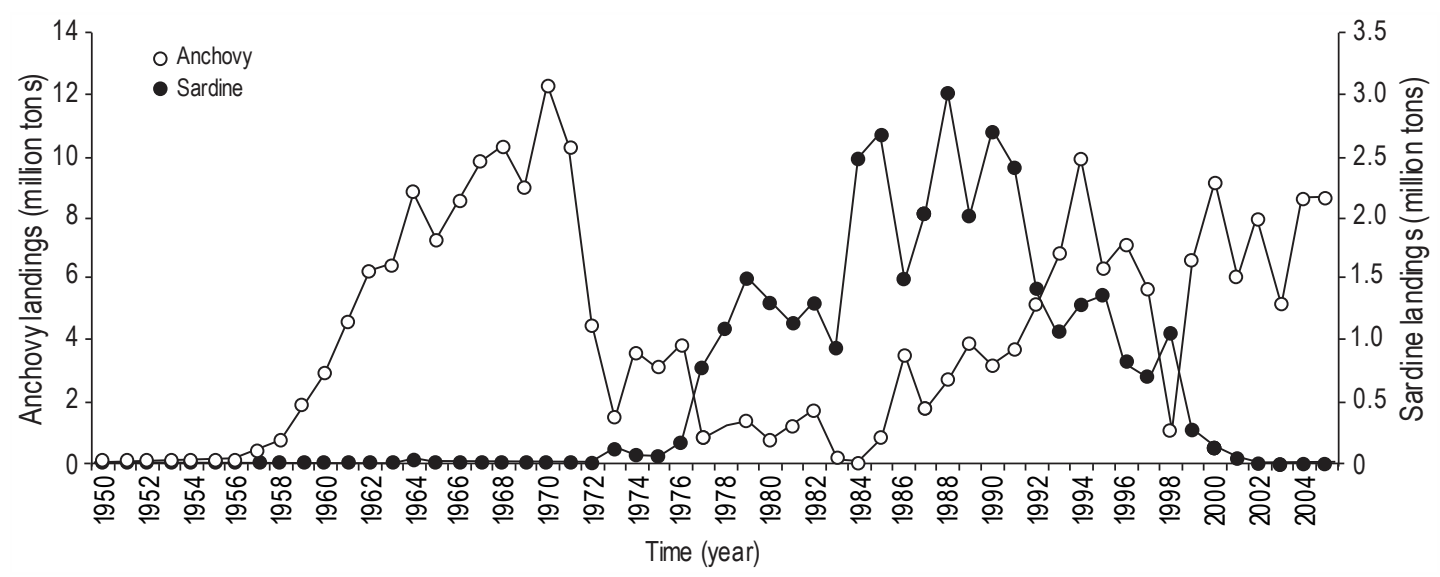

Figure 5. Alternation of sardine (Sardinops sagax) and anchovy (Engraulis ringens) landings on the Peruvian coast. Time series: 1950-2005. Figura 5. Alternancia en los desembarques de sardina (Sardinops sagax) y anchoveta (Engraulis ringens) en el litoral peruano. Serie histórica: 1950-2005.

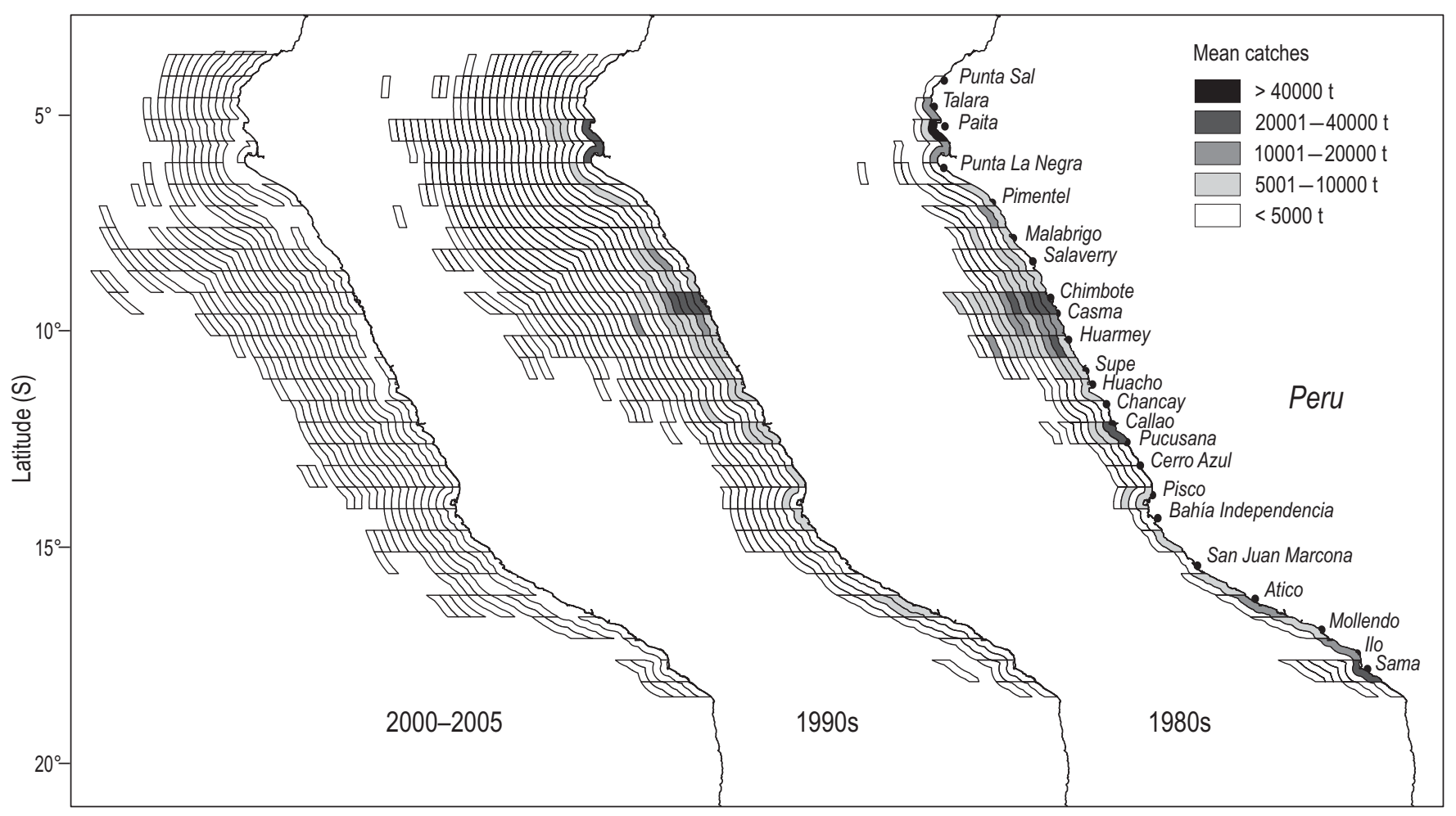

Figure 6. Spatiotemporal distribution of sardine (Sardinops sagax) by fishing areas during the 1980s, 1990s, and 2000-2005.

Figura 6. Distribución espaciotemporal de sardina (Sardinops sagax) según las áreas de pesca durante las décadas de 1980 y 1990 , y el periodo 2000-2005. 


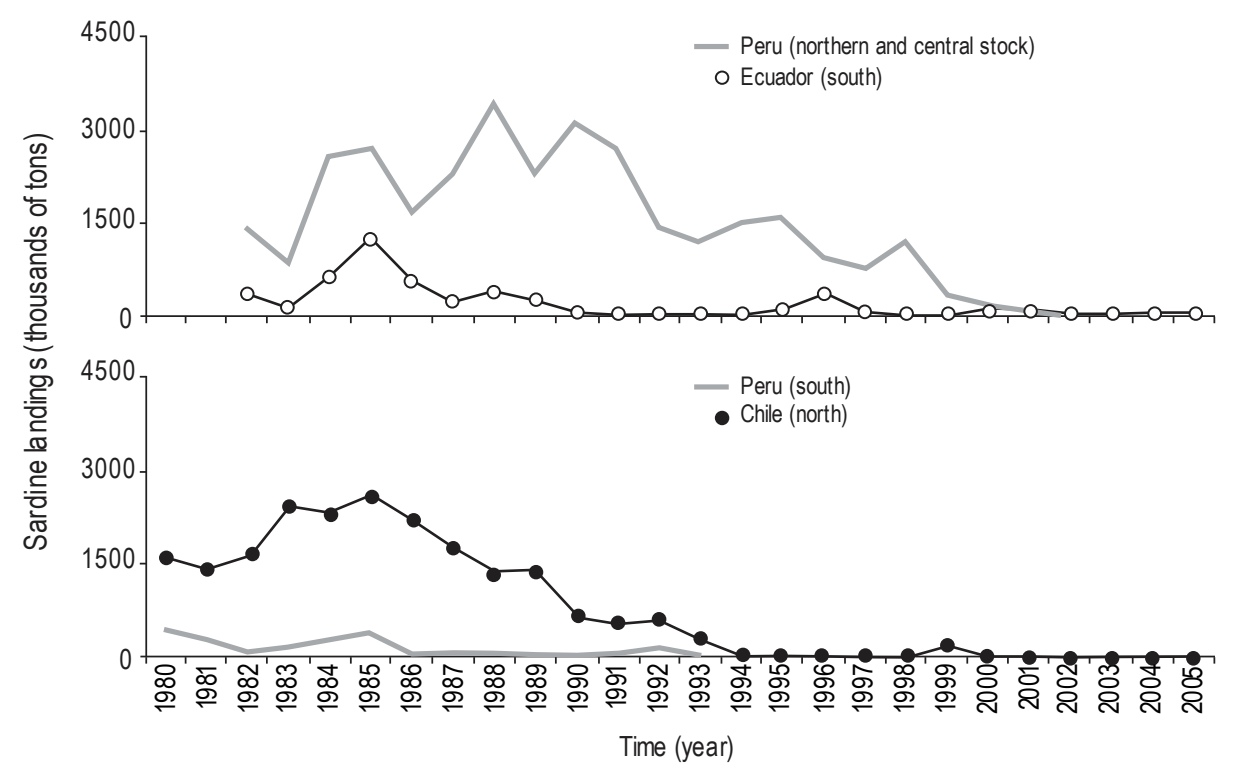

Figure 7. Sardine (Sardinops sagax) landings (1980-2005): (a) northern-central Peru and southern Ecuador stock, and (b) southern Peru and northern Chile stock.

Figura 7. Desembarques de sardina (Sardinops sagax) entre 1980 y 2005: (a) población pesquera del norte-centro del Perú y sur de Ecuador y (b) población pesquera del sur del Perú y norte de Chile.

\section{Variability of sardine abundance in relation to environmental factors}

There was a significant correlation between the sardine landing anomalies and the environmental indicators (PDO index, SOI, and SSTA). The landing anomalies showed a positive correlation with the PDO index. The very low landings from 1961 to 1975 were associated with negative values; between 1979 and 1990, when the landings increased, the PDO index values were positive; and after 1999, the trend reverted to that observed in the earlier years. This indicates long-term fluctuations of sardine landings, that is, periods of high and low yields (fig. 8a).

The SOI also confirmed this long-term fluctuation of sardine landings during the cold and warm periods of the historical series from 1961 to 2005 associated with positive and negative values of this index (fig. 8b). Likewise, the landings increased and decreased when the SSTA values were positive or negative, respectively (fig. 8c). Analysis of the Pearson correlation coefficient values showed that the PDO index had a significant positive correlation with the sardine landing anomalies $\left(r_{\text {Pearson }}=0.50 ; P=0.0005 ; n=45\right)$ compared with the other indices (SOI and SSTA) (table 2).

\section{DISCUSSION}

Our results indicate that overcapacity of the industrial fleet targeting anchovy in the early 1970s $(\sim 1500$ vessels with a $\mathrm{HC}$ of $260,000 \mathrm{~m}^{3}$ ) led to the collapse of the fishery and the onset of the commercial sardine fishery in the late negativos de este índice (fig. 8b). También, los desembarques se incrementaron o decrecieron cuando las ATSM fueron positivas o negativas, respectivamente, tal como se observó con los otros indicadores (fig. 8c). Los valores del análisis del coeficiente de correlación de Pearson indicaron que el IODP tuvo una significativa correlación positiva con las anomalías de los desembarques de sardina $\left(r_{\text {pearson }}=0.50\right.$; $P=0.0005 ; n=45)$ en comparación con los otros índices (IOS y ATSM) (tabla 2).

\section{DISCUSIÓN}

Los resultados obtenidos en este trabajo mostraron que a inicios de la década de 1970 hubo una sobrecapacidad de la flota industrial, con alrededor de 1500 embarcaciones y $260,000 \mathrm{~m}^{3}$ de $\mathrm{CB}$; este esfuerzo estuvo dirigido principalmente a la anchoveta. A finales de esta década se inició la pesquería industrial de sardina, como consecuencia del colapso de la pesquería de anchoveta. En los años ochenta, período de mayor captura de sardina, la capacidad de la flota decreció a 89,946 $\mathrm{m}^{3}$, pero esta nueva capacidad fue suficiente para el desarrollo de la pesquería.

Sin embargo, a partir de la década de 1990, nuevamente se observó un incremento en el número de embarcaciones, que llegó hasta 642, y en la CB, que aumentó a alrededor de $155,000 \mathrm{~m}^{3}$ entre 1994 y 1998 . A pesar de que en este período el número de embarcaciones no fue tan grande como en los años setenta, las embarcaciones de cerco (bolicheras) presentaron un mayor poder de pesca debido al desarrollo tecnológico: composición y renovación de equipos de pesca, 

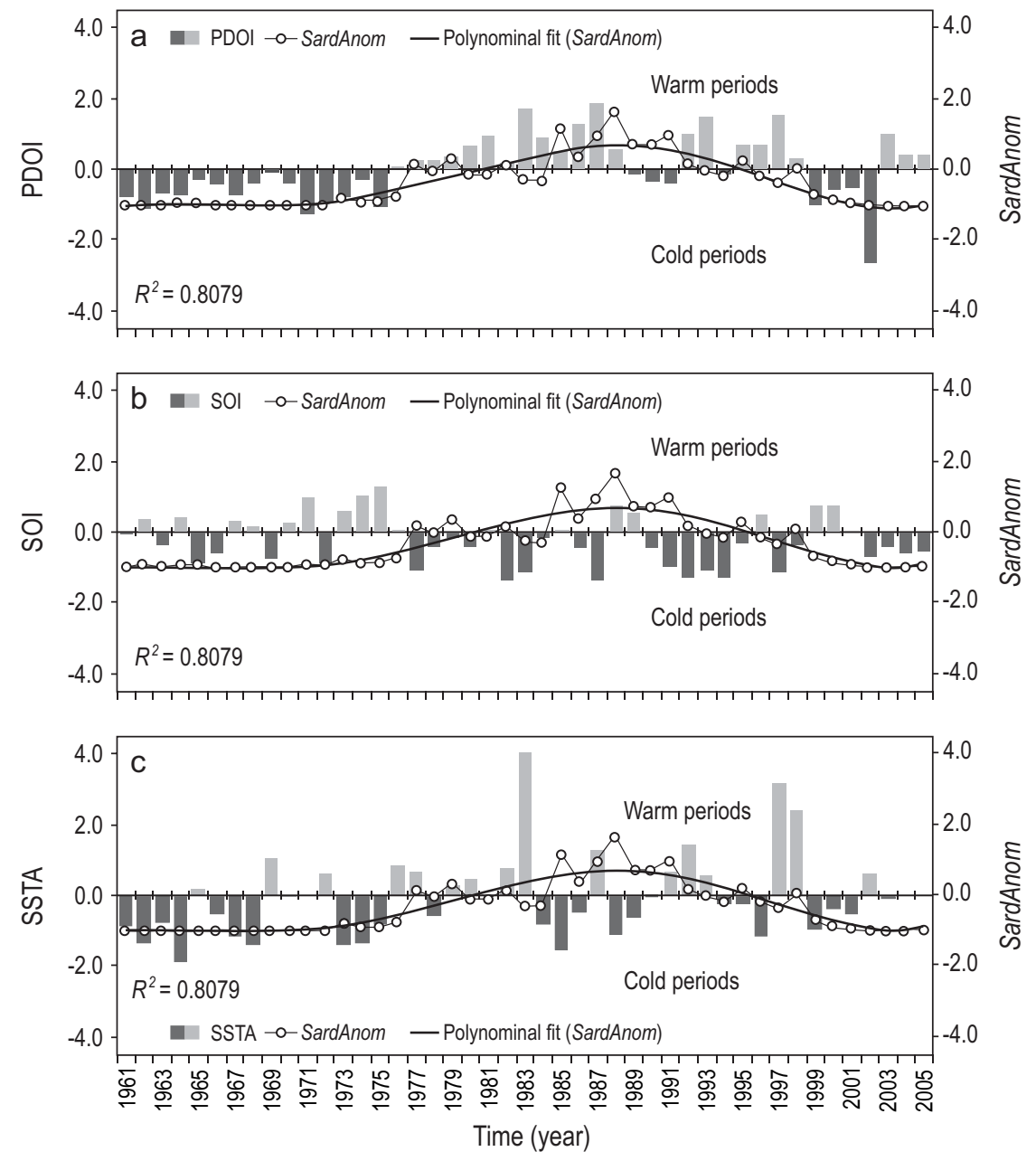

Figure 8. Relationship of sardine (Sardinops sagax) landing anomalies (SardAnom): (a) Pacific Decadal Oscillation Index (PDOI), (b) Southern Oscillation Index (SOI), and (c) Sea Surface Temperature Anomaly (SSTA, data from the Chimbote station). The polynomial fit for SardAnom is also shown. Time series: 1961-2005.

Figura 8. Relación de las anomalías de los desembarques de sardina (Sardinops sagax; SardAnom) con (a) el Índice de Oscilación Decadal del Pacífico (PDOI), (b) el Índice de Oscilación del Sur (SOI) y (c) las Anomalías de la Temperatura Superficial del Mar (SSTA, estación Chimbote). Se muestra el ajuste polinomial para SardAnom. Serie histórica: 1961-2005.

1970s. During the 1980s when the sardine catch levels were highest, the fleet HC had decreased to $89,946 \mathrm{~m}^{3}$, but proved to be sufficient for the development of the fishery.

During the 1990s, however, the number of vessels increased to 642, and between 1994 and 1998 the HC of the sardine fleet was $155,000 \mathrm{~m}^{3}$. Even though the number of vessels comprising the fleet was lower than during the 1970s, the fishing power was greater due to improved fish-finding technology, renewal of fishing gear, net modifications, and increased $\mathrm{HC}$ of the individual vessels. These improvements allowed greater mobility to areas of concentration and increased efficiency in view of the changes in sardine distribution, concentration, and behavior. Csirke and Gumy (1996) reported the existence of a fundamental problem related to the overcapacity of the fishing fleet and fish plants in Peru in the early 1990s. modificaciones en las redes y, sobretodo, ampliación de la CB por embarcación. Esto permitió una mayor capacidad de desplazamiento hacia áreas y núcleos de concentración y, por lo tanto, un incremento en la eficiencia ante los cambios en la distribución, concentración y comportamiento de la sardina. Csirke y Gumy (1996) también señalaron que existió un problema fundamental relacionado con la enorme sobrecapacidad de flota y plantas pesqueras en el Perú a principios de la década de 1990.

Con la ocurrencia del evento El Niño 1997-1998, se originó una drástica disminución de la anchoveta, lo que propició la gran disponibilidad de sardina, mayormente juvenil (0, 1, 2 y 3 años de edad). La sardina fue sometida a una fuerte presión de pesca debido al incremento del esfuerzo pesquero, principalmente en 1998, que aunado al evento El Niño impactó negativamente sobre la población de sardina 
Table 2. Correlation of sardine landing anomalies (SARD) vs the environmental indices (SOI, Southern Oscillation Index; PDOI, Pacific Decadal Oscillation Index; SSTA, Sea Surface Temperature Anomaly) based on the Pearson correlation coefficient. Time series: 1961-2005.

Tabla 2. Correlación de las anomalías de los desembarques de sardina (SARD) vs los índices ambientales (SOI, Índice de la Oscilación del Sur; PDOI, Índice de la Oscilación Decadal del Pacífico; SSTA, Anomalías de la Temperatura Superficial del Mar) con base en el coeficiente de correlación de Pearson. Serie histórica:1961-2005.

\begin{tabular}{|c|c|c|c|c|c|}
\hline$r_{\text {Pearson }}$ & Year & SARD & SOI & PDOI & SSTA \\
\hline SARD & 0.300 & 1.000 & -0.220 & 0.500 & 0.140 \\
\hline PDOI & 0.310 & 0.500 & -0.440 & 1.000 & 0.450 \\
\hline SSTA & 0.310 & 0.140 & -0.670 & 0.450 & 1.000 \\
\hline Year & 45 & 45 & 45 & 45 & 42 \\
\hline SARD & 45 & 45 & 45 & 45 & 42 \\
\hline SOI & 45 & 45 & 45 & 45 & 42 \\
\hline PDOI & 45 & 45 & 45 & 45 & 42 \\
\hline SARD & 0.0464 & & 0.1442 & 0.0005 & 0.3679 \\
\hline SOI & 0.1749 & 0.1442 & & 0.0023 & 0.0000 \\
\hline PDOI & 0.0353 & 0.0005 & 0.0023 & & 0.0026 \\
\hline SSTA & 0.0468 & 0.3679 & 0.0000 & 0.0026 & \\
\hline
\end{tabular}

During the 1997-1998 El Niño event, there was a notable decrease in anchovy and greater availability of sardine, mainly juveniles $(0,1,2$, and 3 years of age). The sardine population, which was already showing signs of deterioration, was subjected to high fishing pressure, especially in 1998, and thus negatively affected (Cárdenas 2009).

A spatial and temporal alternation between sardine and anchovy stocks has occurred over the past three decades. During the 1980s, the main fishing grounds were occupied by sardine and the higher catch levels reflected the increase in biomass; this period is known as the "sardine decade". Santander (1981) attributed the dominance of sardine to more extensive spawning grounds, an increase in the number of eggs, and an expansion of the distribution area. The opposite occurred during the 1990s, when anchovy dominated, and during the period 2000-2005, sardine disappeared from the traditional fishing grounds.

Sardine/anchovy alternations have been reported for other upwelling areas, for example, between Sardinops caeruleus and Engraulis mordax off California and between Sardinops melanostictus and Engraulis japonicus off Japan (LluchBelda et al. 1989, Klyashtorin 1998, Bakun and Cury 1999, Bakun and Broad 2003), possibly related to large-scale climate changes (Kawasaki 1983, Kawasaki and Omori 1988, Lluch-Belda et al. 1992). Van der Lingen et al. (2006), based on morphological evidence in the feeding apparatus of que ya venía mostrando signos de deterioro poblacional (Cárdenas 2009).

Durante las últimas tres décadas existió una alternancia espacial y temporal entre la abundancia de las poblaciones pesqueras de sardina y anchoveta. En la década de 1980, la sardina ocupó extensas áreas de pesca y el incremento de la biomasa poblacional se reflejó en las mayores capturas; este periodo se considera como la "década sardinera". Santander (1981) atribuyó la dominancia de sardina a una mayor extensión de las áreas de desove, un incremento en el número de huevos y una expansión del área de distribución. Lo contrario sucedió durante la década de 1990, cuando predominó la anchoveta. En el período 2000-2005 la sardina desapareció de las áreas tradicionales de pesca.

La alternancia en la abundancia de la sardina y la anchoveta también ha sido reportada en otras áreas de afloramiento, como entre Sardinops caeruleus y Engraulis mordax en California y entre Sardinops melanostictus y Engraulis japonicus en Japón (Lluch-Belda et al. 1989, Klyashtorin 1998, Bakun y Cury 1999, Bakun y Broad 2003), tal vez asociada a cambios climáticos de gran escala (Kawasaki 1983, Kawasaki y Omori 1988, Lluch-Belda et al. 1992). Van der Lingen et al. (2006), con base en evidencias morfológicas del aparato digestivo de la anchoveta y sardina, hipotetizaron que la alternancia de estas especies está probablemente basada en la competencia por $\mathrm{y}$ adaptación a recursos alimenticios 
anchovy and sardine, hypothesized that alternations between these species are likely motivated by the competition for and adaptation to specific food sources. This trophodynamic hypothesis relates changes in physical and oceanological regimes and the plankton community with changes in anchovy and sardine dominance under bottom-up processes.

Ayón et al. (2008) related time series of anchovy and sardine landings to zooplankton biovolumes. The zooplankton biovolumes and anchovy landings are globally in phase, whereas the zooplankton biovolumes and sardine landings are out of phase, especially when the nocturnal biovolumes are considered. This provides clear evidence of the bottomup control of zooplankton on the anchovy population but not on the sardine population and requires further investigation.

The spatial and temporal distribution of S. sagax showed greater alterations during ENSO events (El Niño and La Niña). During El Niño 1982-1983, one of the most intense events on record, this species migrated southwards from its traditional fishing grounds off northern Peru (Tsukayama and Santander 1983, Vela and Rubio 1985, Cañón 1985).

Three ENSO events occurred during the 1990s: La Niña 1995-1996, La Niña 1999, and El Niño 1997-1998, the latter of great intensity. During the two La Niñas, when upwelling intensified, the latitudinal and longitudinal distribution of S. sagax increased ( $<200 \mathrm{~nm}$ offshore). During El Niño 1997-1998, the marine environment experienced important changes due to the advance or input of Equatorial Surface Water and Subtropical Surface Water, which conditioned the distribution of the sardine fishing grounds, but not as strongly as during El Niño 1982-1983.

The changes observed in the distribution of $S$. sagax reveal considerable interannual variations in migration, mainly during intense El Niño events, when its distribution deepened and it migrated southwards in search of better survival conditions (food). These alterations, however, have not been observed in other ecosystems. Under normal conditions, the California sardine (S. caeruleus) migrates northwards from its spawning grounds in the south to feed (Bailey et al. 1982, Schwartzlose et al. 1999). Agostini (2005) reported that the pelagic habitat is dynamic and its limits present spatial and temporal changes related to physical oceanographic variables. Nonetheless, the mechanisms causing these changes are not clear and the migratory behavior of sardines is not yet fully understood.

For the past 50 years, a significant correlation was observed between the environmental indicators (PDO index, SOI, and SSTA) and the sardine landing anomalies, which showed long-term fluctuations with periods of high and low yields, thus corroborating the decadal changes. Decadal-scale changes in distribution and concentration, influenced by environmental variations, are not only associated with seawater temperature, but also with other factors such as dissolved oxygen levels in the water column, food availability, and prey size (Bertrand et al. 2011). específicos. Esta hipótesis trofodinámica relaciona cambios en los regímenes físicos y oceánicos y la comunidad planctónica con cambios en la dominancia de anchoveta y sardina bajo procesos de tipo ascendente (bottom-up).

Ayón et al. (2008) relacionaron series de tiempo de desembarques de anchoveta y sardina con biovolúmenes de zooplancton. Los biovolúmenes del zooplancton y los desembarques de anchoveta están globalmente en fase, mientras que los biovolúmenes del zooplancton y los desembarques de sardina están fuera de fase, en particular cuando se consideran los biovolúmenes nocturnos. Lo anterior provee fuerte evidencia del control ascendente por el zooplancton sobre la población de anchoveta, mas no sobre la sardina, por lo que es necesario seguir investigando.

La distribución espaciotemporal de $S$. sagax presentó mayores alteraciones en durante los eventos ENSO ("El Niño" y “La Niña”). Durante El Niño 1982-1983, catalogado como extraordinario, la sardina realizó migraciones desde las áreas tradicionales de pesca en el norte hacia el sur del litoral peruano (Tsukayama y Santander 1983, Vela y Rubio 1985, Cañón 1985).

En la década de 1990, ocurrieron tres eventos ENSO: La Niña 1995-1996, La Niña 1999 y El Niño 1997-1998, este último de gran intensidad. Durante las Niñas, cuando se intensificó el afloramiento, la sardina amplió su distribución latitudinal y longitudinal (sobrepasó las $200 \mathrm{mn}$ de la costa). Durante el Niño 1997-1998, se observaron cambios importantes en el ambiente marino debido al avance o ingreso de Aguas Ecuatoriales Superficiales y de Aguas Subtropicales Superficiales. Esto cambios condicionaron la distribución de las zonas de pesca de la sardina, pero con menor impacto comparado con El Niño 1982-1983.

Los cambios observados en la distribución de sardina indicaron una considerable variabilidad interanual en su comportamiento migratorio, principalmente durante los eventos El Niño de gran intensidad; durante estos eventos, la sardina se profundizó y luego migró hacia la zona sur en busca de mejores condiciones (alimento) para su supervivencia. Por el contrario, en otros ecosistemas no se han reportado estas alteraciones. La sardina de California (S. caeruleus), durante condiciones normales, realiza migraciones desde sus áreas de desove en el sur hacia el norte para alimentarse (Bailey et al. 1982, Schwartzlose et al. 1999). Agostini (2005) encontró que el hábitat pelágico es dinámico y sus límites presentan cambios espaciotemporales relacionados con variables oceanográficas físicas; sin embargo, los mecanismos causantes de estos cambios no están claros, por lo que el comportamiento migratorio de la sardina aún no está bien comprendido.

En los últimos 50 años se ha observado una correlación significativa entre los indicadores ambientales (IODP, IOS y ATSM) y las anomalías de los desembarques de sardina, que mostraron cambios de largo plazo, con períodos de altos y bajos rendimientos, corroborándose así los cambios decadales. Los cambios notables a escala decadal en la distribución y concentración de sardina, influenciados por la variabilidad 
Variations in fish catches can be seen as indicators of resource abundance and availability (Melo-Barrera et al. 2010). In Peruvian waters, the high fishing pressure exerted on S. sagax by the industrial purse-seine fleet (translated into number of vessels and HC) strongly affected the abundance of this species that began declining in the mid-1990s. Sardine landings decreased from an average of 2.5 million tons during the period 1987-1992 to $304 \mathrm{t}$ between 2002 and 2005, clear evidence of the collapse of the fishery, which was also affected by the extraordinary 1997-1998 El Niño event.

\section{ACKNOWLEDGMENTS}

The authors thank the staff of the IMARPE coastal labortories for providing the sardine plant and landing data used in this study.

English translation by Christine Harris.

\section{REFERENCES}

Agostini VN. 2005. Climate, ecology and productivity of Pacific sardine (Sardinops sagax) and hake (Merluccius productus). $\mathrm{PhD}$ thesis, University of Washington, $160 \mathrm{pp}$.

Ayón P, Swartzman G, Bertrand A, Gutiérrez M, Bertrand S. 2008. Zooplankton and forage fish species off Peru: Large-scale bottom-upforcing and local-scale depletion. Prog. Oceanogr. 79: 208-214.

Bailey KM, Stevens PR. 1982. The life history and fishery of Pacific whiting, Merluccius productus. CalCOFI Rep. 23: 81-98.

Bakun A, Cury P. 1999. The school traps: A mechanism promoting large-amplitude out-of-phase population oscillations of small pelagic fish species. Ecol. Lett. 2(6): 349-351.

Bakun A, Broad K. 2003. Environmental "loopholes" and fish populations' dynamics comparative pattern recognition with focus on El Niño effects in the Pacific. Fish. Oceanogr. 12: 458-473.

Bertrand A, Chaigneau A, Peraltilla S, Ledesma J, Graco M, Monetti F, Chávez F. 2011. Oxygen: A fundamental property regulating pelagic ecosystem structure in the coastal southeastern tropical Pacific. PLoS ONE 6(12): 1-8.

Cañón JR. 1985. La variabilidad ambiental en la zona norte de Chile y su influencia en la pesquería pelágica durante El Niño 1982-1983. Invest. Pesq. (Chile) 32: 119-28.

Cárdenas G. 2009. Análisis de series de tiempo de los indicadores biológicos, pesqueros y poblacionales de la sardina, Sardinops sagax (Jenyns 1842), en función de la variabilidad ambiental y la pesca. PhD thesis, Universidad Nacional Mayor de San Marcos, Lima, Perú, 131 pp.

Cárdenas G, Chipollini A, Cedeño I, González N. 1997. Evaluación conjunta del stock de sardina (Sardinops sagax) de la región norte-centro de Perú y sur de Ecuador, 1982-1996. I Taller de Evaluación de Pequeños Pelágicos, IMARPE-VECEP (Programa de Pesca UE), Lima, Perú, 13-31 October 1997, pp. 1-26.

Chávez FP, Ryan J, Lluch-Cota S, Ñiquen M. 2003. From anchovies to sardines and back: Multidecadal change in the Pacific Ocean. Science 299: 217-221.

Csirke J, Gumy A. 1996. Análisis bioeconómico de la pesquería pelágica peruana dedicada a la producción de harina y aceite de pescado. Bol. Inst. Mar Perú (Callao) 15(2): 25-68. ambiental, no sólo están asociados a la temperatura del agua de mar, sino también a otros factores como disponibilidad de oxígeno disuelto en la columna de agua, alimento y tamaño de la presa (Bertrand et al. 2011).

Las variaciones en las capturas de sardina pueden ser vistas como indicadores de la abundancia y la disponibilidad de los recursos (Melo-Barrera et al. 2010). En el mar peruano, el gran esfuerzo de pesca (traducido en número de embarcaciones y CB) de la flota industrial de cerco ejercido sobre S. sagax, impactó fuertemente sobre su abundancia, que venía declinando desde mediados de los años noventa. Las capturas disminuyeron de un promedio de 2.5 millones de toneladas en el período 1987-1992 a 304 t entre 2002 y 2005, lo cual evidenció el colapso de la pesquería, que también estuvo influenciado por El Niño extraordinario de 1997-1998.

\section{Agradecimientos}

Los autores agradecen al personal de los laboratorios costeros del IMARPE la obtención de los datos de los muestreos en las plantas y muelles pesqueros, que hicieron posible la realización del presente trabajo.

Cury P, Bakun A, Crawford RJM, Jarre A, Quiñones RA, Shannon LJ, Verheye HM. 2000. Small pelagics in upwelling systems: Patterns of interaction and structural changes in "wasp-waist" ecosystems. ICES J. Mar. Sci. 57: 603-618.

[FAO] Food and Agriculture Organization. 2007. El Estado Mundial de la Pesca y la Agricultura. SOFIA. FAO, Rome, 176 pp.

Kawasaki T. 1983. Why do some pelagic fishes have wide fluctuations in their numbers? Biological basis of fluctuation from the viewpoint of evolutionary ecology. In: Sharp GD, Csirke J (eds.), Reports of the Expert Consultation to Examine Changes in Abundance and Species Composition of Neritic Fish Resources. FAO Fish. Rep. 291: 1065-1080.

Kawasaki T, Omori M. 1988. Fluctuaciones en las tres poblaciones más importantes de sardina del Pacífico y la tendencia global de la temperatura. In: Wyatt T, Larrañeta MG (eds.), Simposio sobre Cambios de Largo Término en Poblaciones de Peces Marinos, Vigo, Spain, pp. 37-53.

Klyashtorin LB. 1998. Long-term climate change and main commercial fish production in the Atlantic and Pacific. Fish. Res. 37: 115-125.

Lluch-Belda D, Crawford RJM, Kawasaki T, MacCall AD, Parrish R, Schwartzlose RA, Smith PE. 1989. World-wide fluctuations of sardine and anchovy stocks: The regime problem. S. Afr. J. Mar. Sci. 8: 195-205.

Lluch-Belda D, Schwartzlose RA, Serra R, Parrish R, Kawasaki TH, Hedgecock D, Crawford JM. 1992. Sardine and anchovy regime fluctuations of abundance in four regions of the world oceans: A workshop report. Fish. Oceanogr. 1: 339-347.

Melo-Barrera F, Félix-Uraga R, Quiñones-Velázquez C. 2010. Análisis de la pesquería de Sardinops sagax en la costa occidental de Baja California Sur, México, durante 2006-2008. Cienc. Pesq. 18(2): 33-46. 
Patterson KR, Zuzunaga J, Cárdenas G. 1992. Size of the South American sardine (Sardinops sagax) population in the northern part of the Peru Upwelling Ecosystem after collapse of anchovy (Engraulis ringens) stocks. Can. J. Fish. Aquat. Sci. 49(9): 1762-1769.

Santander H. 1981. Patrones de distribución y fluctuaciones de desoves de anchoveta y sardina. In: Dickie LM, Valdivia JE (eds.), Investigación Cooperativa de la Anchoveta y su Ecosistema (ICANE) entre Perú y Canadá. Boletín del Instituto del Mar de Perú, Callao, volumen extraoridinario, pp. 180-192.

Schwartzlose RA, Alheit J, Bakun A, Baumgartner TR, Cloete R, Crawford RJM, Fletcher WJ, Green-Ruiz Y, Hagen E, Kawasaki T, Lluch-Belda D, Lluch-Cota SE, MacCall AD, Matsuura Y, Nevárez-Martínez MO, Parrish RH, Roy C, Serra R, Shust KV,
Ward MN, Zuzunaga J. 1999. Worldwide large-scale fluctuations of sardine and anchovy populations. S. Afr. J. Mar. Sci. 21: 289-347.

Tsukayama I, Santander H. 1983. Recursos pelágicos y sus pesquerías en Perú. Rev. Com. Perm. Pacífico Sur 13: 25-63.

Van der Lingen CD, Hutchings L, Field JG. 2006. Comparative trophodynamics of anchovy Engraulis encrasicolus and sardine Sardinops sagax in the southern Benguela: Are species alternations between small pelagic fish trophodynamically mediated? Afr. J. Mar. Sci. 28: 465-477.

Vela J, Rubio J. 1985. Movimientos migratorios de la sardina determinados por marcaciones. In: Tresierra A (ed.), Actas 1er Congreso Nacional de Biología Pesquera. Colegio Regional del Norte, Trujillo, Peru, pp. 71-74.

Received September 2014, accepted February 2015. 